INTERNATIONAL BULLETIN OF BACTERIOLOGICAL NOMENCLATURE AND TAXONOMY

Volume 8 No. 1 January 15, 1958 pp. 25-70

\title{
REPORT OF THE ENTEROBACTERIACEAE SUBCOMMITTEE OF THE NOMENCLATURE COMMITTEE OF THE INTERNATIONAL ASSOCIATION OF MICROBIOLOGICAL SOCIETIES
}

(To be presented to the International Committee on Bacteriological Nomenclature at the VII International Congress of Microbiology, 1958.)

\section{Membership of the Enterobacteriaceae Subcommittee}

Chairman: Dr. E. Hormaeche, Montevideo, Uruguay

Secretary: Dr. W. W. Ferguson, Lansing, Michigan, U.S.A.

Members: Dr. D. W. Bruner, Ithaca, New York, U.S.A.

Lt. Col. P. R. Carlquist, Fort Sam Houston,

Texas, U.S.A.

Dr. K. P. Carpenter, London, England

Dr. S. T. Cowan (ex officio), London, England

Dr. P. R. Edwards, Atlanta, Georgia, U.S.A.

Dr. W. H. Ewing, Atlanta, Georgia, U.S.A.

Dr. A. Giovanardi, Milan, Italy

Dr. F. Kauffmann, Copenhagen, Denmark

Dr. L. LeMinor, Paris, France

Dr. K. Rauss, Pecs, Hungary

Dr. H. Seeliger, Bonn, Germany

Dr. C. A. Stuart, Providence, Rhode Island,

U.S.A.

Dr. J. Taylor, London, England

\section{ENTEROBACTERIACEAE}

\section{Definition and Principles of Classification}

The family Enterobacteriaceae is composed of Gram-negative rod-shaped bacteria, which are motile with peritrichous flagella or nonmotile. They ferment glucose rapidly with or without gas production, reduce nitrates to nitrites, and grow on ordinary media.

The principles of classification given in the 1950 and 1953 Enterobacteriaceae Reports " are reaffirmed. However,

TInternational Bulletin of Bacteriological Nomenclature and Iaxonomy, 4:1-94. 1954. 
these principles are restated here for purposes of emphasis, clarity, and convenience.

The family Enterobacteriaceae is made up of a series of interrelated bacterial types and segregation of these into groups often is difficult because the transition from group to group is gradual and intermediate forms exist in all instances. However, within the family there are dense centers of population composed of biochemically homogeneous bacteria, which also show a high degree of serological relationship, and it is these centers that form the biochemical groups mentioned herein.

In turn, the principal biochemical groups within the family are divided into subgroups on the basis of serology, on certain biochemical reactions, or by a combination of both methods. Generally, the groups are divided into subgroups on the basis of the $O$ antigens of the bacteria, as in the case of the Salmonella, Arizona, Citrobacter, Escherichia, Providence, and Serratia groups. The $O$ antigen subgroups are further divided into serotypes, which are characterized by the possession of particular $O$ antigen fractions, $K$ (sheath or capsular) antigens, or H (flagellar) antigens. Further, some serotypes may be composed of two or more biotypes. Some groups are divided into subgroups by means of a combination of biochemical and serologic characteristics. For example, the Shigella group is composed of four subgroups, which are differentiated by means of the serological and biochemical characteristics of the serotypes contained in each subgroup. In the Klebsiella group, subdivision generally is made directly into serotypes by means of capsular antigen determination, although several 0 antigen groups are known. Also, three principal biochemical subgroups are recognized within the Klebsiella group; these correspond to the species Klebsiella pneumoniae, $\underline{K}$. rhinoscleromatis, and $\underline{K}$. ozaenae. At present, the Proteus group is subdivided on the basis of biochemical reactions alone, although an antigenic schema has been established for a portion of the group (Proteus vulgaris and . mirabilis). Certain other principal biochemical groups such as the Cloaca (Aerobacter) and Hafnia groups have not been subdivided.

Some serotypes within certain groups may be composed of two or more biotypes, as is the case, for example, with cer- 
tain salmonellae. In some instances, particular biotypes or serotypes have been given specific names (e.g., Salmonella typhi or $\mathrm{K}$. ozaenae) that are generally recognized. However, it should be emphasized that all of the serotypes within the groups are not regarded as species. On the contrary, only one species of Escherichia is recognized but there are many E. coli serotypes and four species are recognized within the Shigella group, each of which contains a number of serotypes, etc.

A report on the Proteus group is not presented at this time. Several proposals have been made regarding the nomenclature and taxonomy of the Proteus and Providence groups and these are being studied by the Subcommittee. Until agreement is reached on this subject, the Subcommittee recommends the continued use of the classification of the Proteus group devised by Rustigian and Stuart $(1945)^{1}$ as in the appended table of biochemical reactions, and the continued maintenance of the Providence group as a separate entity.

Also, no report on the Alkalescens-Dispar group is presented since its status largely remains unchanged. This group actually is composed of anaerogenic nonmotile $\underline{E}$. coli biotypes that belong to various E. coli $O$ antigen groups and ma be reported as such if desired.

Since the majority of the Subcommittee members prefer the terms "groups" and "types" to "genera" and "species", only common names are used in the report. However, the group names may be used in a generic sense and with generic connotation if desired.

The definitions and descriptions of the various groups of Enterobacteriaceae are given in the following pages. Attention should be directed to the fact that in those groups in which the bacteria are described as motile, nonmotile variants may occur. The key to the symbols used in the definitions of the groups, and in the appended table of biochemical reactions, is as follows:

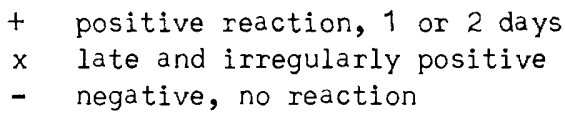

Tour. Bact. 49:419. 1945. 


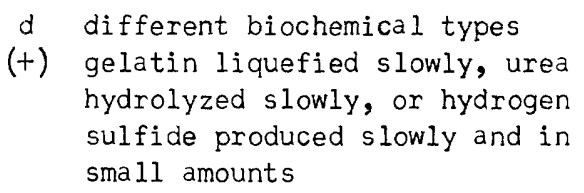

The term phenylalanine deaminase employed in the definitions and the table refers to the enzyme system that is responsible for the oxidative deamination of phenylalanine to phenylpyruvic acid.

A list of "Recommended biochemical methods for group differentiation within the Enterobacteriaceae", which has been approved by the majority of the Subcommittee members, is appended to this report. It is suggested that these methods be employed in the interests of uniformity and better taxonomy.

THE SALMONELLA GROUP

(Sixth Report)

Salmonella Definition

The Salmonella group consists of motile or nonmotile bacteria that conform to the definition of the family Enterobacteriaceae, and have the following biochemical characteristics:

$\begin{array}{lc}\text { Gas from glucose } & + \\ \text { Lactose } & - \\ \text { Sucrose } & - \\ \text { Mannitol } & + \\ \text { Dulcitol } & + \\ \text { Salicin } & - \\ \text { Adonitol } & - \\ \text { Inositol } & d \\ \text { Indol } & - \\ \text { Methyl red } & + \\ \text { Voges-Proskauer } & - \\ \text { Armonium citrate } & + \\ \text { Hydrogen sulfide } & + \\ \text { Urease } & - \\ \text { Gelatin liquefaction } & - \\ \text { Growth in KON medium } & -\end{array}$


B ACTERIOLOGICAL NOMENCLATURE A N D I A X O N O M Y

\section{Phenylalanine deaminase - \\ Sodium malonate \\ Newly Recognized Serotypes}

A list of Salmonella serotypes recognized by the Subcommittee in the interval between the publication of the 1953 Report and December 31, 1957 will be published as a supplement to this report. These serotypes may be inserted into the Kauffmann-White Schema (see Fifth Salmonella Report, International Bulletin, 4:54-72. 1954. and Fourth Salmonella Report, ibid., $4: 11-1 \overline{7} .1954$.

THE ARIZONA GROUP

(Third Report)

\section{Arizona Definition}

The Arizona group consists of motile bacteria that conform to the definition of the family Enterobacteriaceae, and have the following biochemical characteristics:

$\begin{array}{lc}\text { Gas from glucose } & + \\ \text { Lactose } & + \text { or } x \\ \text { Sucrose } & - \\ \text { Mannitol } & + \\ \text { Dulcitol } & - \\ \text { Salicin } & - \\ \text { Adonitol } & - \\ \text { Inositol } & - \\ \text { Indol } & - \\ \text { Methyl red } & + \\ \text { Voges-Proskauer } & - \\ \text { Ammonium citrate } & + \\ \text { Hydrogen sulfide } & + \\ \text { Urease } & - \\ \text { Gelatin liquefaction } & (+) \\ \text { Growth in KCN medium } & - \\ \text { Phenylalanine deaminase } & - \\ \text { Sodium malonate } & +\end{array}$


Page 30

The second report is affirmed. In the interim additional $O$ and $H$ antigens were recognized and many new serotypes established. At present, 320 groups, $37 \mathrm{H}$ antigens and 144 serotypes are known. The KCN test of Moeller (1) and the ninhydrin test of Carlquist (2) have been used to differentiate Arizona from Citrobacter strains. The Arizona group fails to grow in KCN medium and is ninhydrin positive, whereas the results of these tests are the reverse with the Citrobacter strains. Shaw (3), Kauffmann and Petersen (4) and Ellis, Edwards and Fife (5) have utilized organic acids ${ }^{1}$ to differentiate typical Salmonella, Citrobacter, and Arizona strains in the following manner.

Mucate D-Tartrate Citrate Malonate

Arizona

Salmonella

Citrobacter

$\begin{array}{llll}- & - & - & + \\ + & + & + & - \\ + & - & - & -\end{array}$

\section{REFERENCES}

1. Acta Path. et Microbiol. Scand. 34:115. 1954.

2. Jour. Bact. 71:339. 1956.

3. Internat1. Bu11. Bact. Nomen. Tax. 6:1. 1956.

4. Acta Path. et Microbiol. Scand. 38:481. 1956.

5. Pub. Health Lab. 15:89. 1957.

\section{THE CITROBACTER GROUP}

(Including the Bethesda-Ballerup group)

(Third Report)

\section{Citrobacter Definition}

The Citrobacter group consists of motile bacteria that conform to the definition of the family Enterobacteriaceae, and have the following biochemical characteristics:

$$
\begin{array}{ll}
\text { Gas from glucose } & + \\
\text { Lactose } & + \text { or } x
\end{array}
$$

Tested in 1.0 per cen peptone solution according to the methods of Kauffmann and Petersen (4). 


$\begin{array}{lc}\text { Sucrose } & d \\ \text { Mannitol } & + \\ \text { Dulcitol } & d \\ \text { Salicin } & d \\ \text { Adonitol } & - \\ \text { Inositol } & - \text { or } x \\ \text { Indol } & - \\ \text { Methyl red } & + \\ \text { Voges-Proskauer } & - \\ \text { Ammonium citrate } & + \\ \text { Hydrogen sulfide } & + \\ \text { Urease } & - \\ \text { Gelatin liquefaction } & - \\ \text { Growth in KCN medium } & + \\ \text { Phenylalanine deaminase } & - \\ \text { Sodium malonate } & -\end{array}$

In the first report on this group only the slow lactose fermenting cultures were included under the Bethesda group and the Ballerup group (provisional). The second report also was confined to those cultures which did not ferment lactose promptly and the organisms were called the Bethesda-Ballerup group. With the exception of slow fermentation of lactose, the organisms thus listed obviously possess biochemical properties similar to those of the organisms classified in Bergey's Manual (1) as Escherichia freundii and by Werkman and Gillen

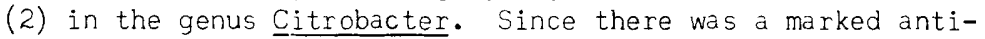
genic continuity between the cultures which fermented lactose rapidly and those which attacked the sugar slowly (West and Edwards, 3) it became obvious that the Bethesda-Ballerup group was only a portion of a larger group previously classified as Escherichia freundii or as Citrobacter. In the interest of clarity of group definitions, the organisms are removed from the Escherichia group and designated as the Citrobacter group.

The members of the Citrobacter group which ferment lactose slowly bear a superficial resemblance to the Salmonella and Arizona groups and often are confused with them. The KCN test of Moeller (4) and the ninhydrin test of Carlquist (5) are of the greatest value in the differentiation of Citrobacter cultures from members of the Salmonella and Arizona 
groups (6). Further, organic acids ${ }^{1}$ as used by Kauffmann and Petersen (7) and Ellis, Edwards, and Fife (8) also are of help in differentiating the organisms. Typical cultures of the three groups give the following patterns of reaction in these tests:

$$
\text { Mucate D-Tartrate Citrate Malonate }
$$

Salmonella

Arizona

Citrobacter

$\begin{array}{llll}+ & + & + & - \\ - & - & - & + \\ + & - & - & -\end{array}$

\section{REFERENCES}

1. Breed, R.S. et al. Bergey's Manual of Determinative Bacteriology, Williams and Wilkins, Baltimore. Ed. 6. 1948. 2. Jour. Bact. 23:167. 1932.

3. U.S. Department of Health, Education and Welfare, Public Health Monograph No. 22, 1954.

4. Acta Path. et Microbiol. Scand. 34:115. 1954.

5. Jour. Bact. 71:339. 1956.

6. Amer. Jour. Med. Tech. 22:28. 1956.

7. Acta Path. et Microbiol. Scand. 38:481. 1956.

8. Public Health Lab. 15:89. 1957.

THE SHIGELLA GROUP

(Third Report)

\section{Shigella Definition}

The Shigella group consists of nonmotile bacteria that conform to the definition of the family Enterobacteriaceae and have the following biochemical characteristics:

$\begin{array}{ll}\text { Gas from glucose } & - \\ \text { Lactose } & - \\ \text { Sucrose } & - \\ \text { Mannitol } & \text { d }\end{array}$

Tested in 1.0 per cent peptone solution according to the methods of Kauffmann and Petersen (7). 
B A C I ER I OL OGICAL NOMENCLA I URE A N D T T A X O N O M Y

$\begin{array}{lc}\text { Dulcitol } & d \\ \text { Salicin } & - \\ \text { Adonitol } & - \\ \text { Inositol } & - \\ \text { Indol } & d \\ \text { Methyl red } & + \\ \text { Voges-Proskauer } & - \\ \text { Ammonium citrate } & - \\ \text { Hydrogen sulfide } & - \\ \text { Urease } & - \\ \text { Gelatin liquefaction } & - \\ \text { Growth in KCN medium } & - \\ \text { Phenylalanine deaminase } & - \\ \text { Sodium malonate } & -\end{array}$

Some biotypes of Shigel la flexneri 6 are known to produce small volumes of gas from glucose and other fermentable substrates. Lactose is not fermented by members of subgroups A, $B$, or $C$, but subgroup $D$ cultures generally ferment it after several days' incubation. Sucrose usually is fermented by cultures of subgroup $D$ upon extended incubation but slow production of acid from sucrose also may occur in cultures of certain serotypes of subgroups $A, B$, and $C$. Mannitol is not fermented by members of subgroup A but acid usually is produced from this substrate by members of subgroups B, C, and D. Hydrogen sulfide is not produced on Kligler's, triple sugar iron, or lead acetate agars.

The Shigella group is divided into four subgroups. These subgroups are differentiated by means of a combination of the biochemical and serological characteristics of the serotypes contained in each subgroup. Within the subgroups the serotypes are characterized by the possession of a distinctive antigen called the type antigen or main antigen. Within certain serotypes, which possess a common type or main antigen, significant differences occur in the subsidiary or group antigens. The term group antigens as used here refers to the antigens that relate the members of a Shigella subgroup to each other or relate a serotype belonging to one Shigella subgroup to a serotype that belongs to a different Shigella subgroup. Subserotypes have been designated to distinguish the more important of such minor divisions, as in subgroup $B$ (Shigella flexneri). Serotypes in a subgroup are designated by Arabic numerals. 
The Shigella schema given in the 1950 Report and the nomenclature and recommendations given in the 1950 and 1953 Reports are reaffirmed. In addition to the recommendations made in the 1950 and 1953 keports, the following characterizations of the composition of the four subgroups are recommended:

Subgroup A, Shigella dysenteriae, is composed of serotypes that characteristically do not ferment mannitol and which serologically are not significantly related to members of Shigella subgroups B or D. Each serotype possesses a type or main antigen by which it can be differentiates from other shigellae. New Shigella cultures that (a) do not produce acid from mannitol, (b) that may or may not be serologically related to one or more of the serotypes in subgroup $A$, and (c) that lack significant group antigen relationships to members of subgroups $B$ or $D$, may be added to subgroup $A$ when the need arises.

Shigella cultures that are closely related to $\underline{S}$. dysenteriae 3 and produce acid from mannitol are known. It is recommended that these exceptional cultures be considered as mannitol positive varieties of $\underline{S}$. dysenteriae 3 for the present.

Subgroup B, Siijgelia flexneri, consists of serotypes that usually produce acid from mannitol and which are interrelated by the possession of common group or subsidiary antigens. However, the serotypes each possess a type or main antigen by which they may be differentiated from other shigellae. Serotypes that differ in their group antigen complexes exist in this subgroup. Thus, two cultures that contain the same type or main antigen may differ in the quality and quantity of the antigens present in their group antigen complexes; e.g. subserotypes $1 \mathrm{a}$ and $1 \mathrm{~b}$.

A qualitative loss variation may ocur in certain subgroup $B$ cultures whereby the type or main antigen is lost and the resultant variant cultures contain only group antigen factors. These variants are referred to as $X$ and $Y$.

Mannitol negative cultures that contain the type antigen of one of the subgroup B serotypes should be classified as mannitol negative varieties of the serotype or subserotype to which they belong. Special designations are not recommended for such varieties. 
New serotypes may be added to subgroup B if they possess group antigens in common with known serotypes and if they contain a new type or main antigen demonstrable by appropriate absorption methods. Similarly, new subserotypes may be admitted if they possess a known type or main antigen and contain a new combination of group antigen factors. However, in classification, undue emphasis should not be given to minor variations in the pattern or content of the group or subsidiary antigens of subgroup B cultures.

Subgroup C, Shigella boydii, is composed of microorganisms that ferment mannitol but which serologically are not related to members of subgroup $B$ (or $D$ ) in a significant way. The serotypes may be distinguished from other shigellae by identification of their type antigens. Subserotypes are known to exist within some subgroup $C$ serotypes.

Mannitol negative varieties of some subgroup $C$ serotypes are known; these should be designated simply as mannitol negative varieties of the serotypes to which they belong.

Subgroup D, Shigella sonnei, consists of microorganisms that biochemically are similar to members of subgroups $B$ and $C$ but which characteristically ferment lactose upon extended incubation. The existence of mannitol negative members of subgroup $D$ is known, however. Only one serotype is included in subgroup $D$ but new serotypes may be added if they are similar to $\underline{S}$. Sonnei in their biochemical characters. The 0 antigens of subgroup $D$ strains are not significantly related to other described shigellea.

The four specific names (Shigella dysenteriae, Shigella flexneri, Shigella boydii, and Shigella sonnei) employed above in connection with Shigella subgroups A, B, C and D, respectively, were conserved by the Judicial Commission as previously recommended by the Shigella Commission and the Enterobacteriaceae Subcommittee (see Opinion 11, approved, and references contained therein, International Bulletin, $4: 148-150$, 1954).

In the 1953 subcommittee Report it was recommended that certain described sub judice Shigella serotypes be considered for possible future addition to the Shigella schema. The status of these serotypes, as well as certain others, will be 
Page 36

I N TER N A T I O NAL BULLE I I N

considered in a supplementary report which will be published at a later date.

Since the purpose for which it was formed was considered to be fulfilled, the ad hoc Shigella Commission, created at the IV International Congress, 1947, was disbanded by majority vote at the Subcommittee meeting held during the VI Congress, Rome, September 6-12, 1953. Matters pertaining to the shigellae are now studied at the International Shigella Centers, by other interested individuals, and by the subcommittee as a whole.

\section{REFERENCES}

Cox, l. D. and Wallace, G. I. 1948. Jour. Immunol. 60:465. Ewing, W. H., Hucks, M. C., and Taylor, M. W. 1952. Jour. Bact. $63: 319$.

Ewing, W. H. and Hucks, M. C. 1952. Jour. Immunol. 69:575.

Ewing, W. H. 1953. Jour. Bact. 66:333. 


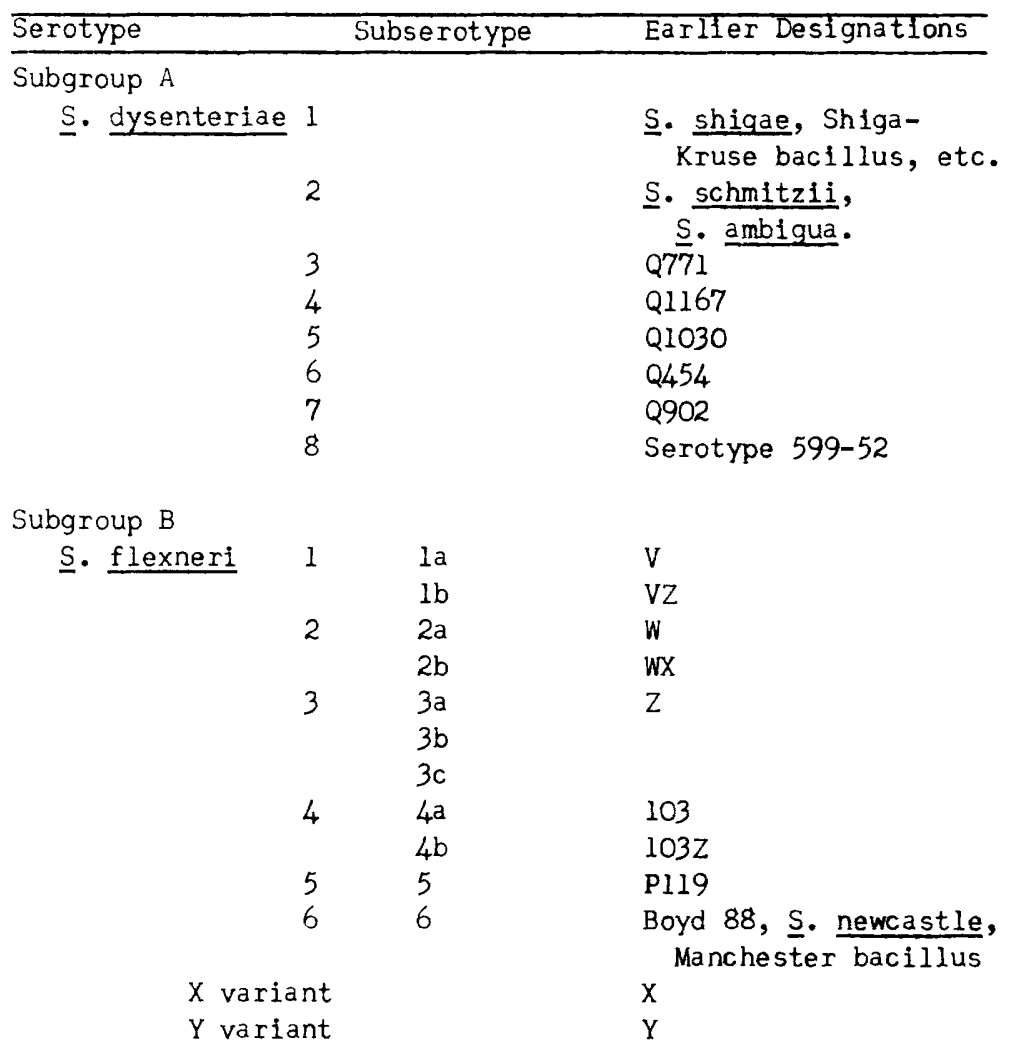

Subgroup C

$\underline{\text { S. boydii }}$

$\begin{array}{rl}1 & 170 \\ 2 & \text { P288 } \\ 3 & \text { D1 } \\ 4 & \text { P274 } \\ 5 & \text { P143 } \\ 6 & \text { D19 } \\ 7 & \text { Lavington, type T, } \\ & \text { S. etousa } \\ 8 & \text { Serotype } 112 \\ 9 & \text { Serotype } 1296 / 7 \\ 10 & \text { Serotype } 430 \\ 11 & \text { Serotype } 34\end{array}$

Subgroup D

S. Sonnei

Sonne-Duval, Sonne III, etc. 
Page 38

I N T E R N A T I ONAL BUL L E T I N

THE ESCHERICHIA GROUP

(Third Report)

\section{Escherichia Definition}

The Escherichia group consists of motile or nonmotile bacteria that conform to the definition of the family Enterobacteriaceae, and have the following biochemical characteristics:

$\begin{array}{lc}\text { Gas from glucose } & + \\ \text { Lactose } & \text { or } x \\ \text { Sucrose } & d \\ \text { Mannitol } & + \\ \text { Dulcitol } & d \\ \text { Salicin } & d \\ \text { Adonitol } & - \\ \text { Inositol } & - \\ \text { Indol } & + \\ \text { Methyl red } & + \\ \text { Voges-Proskauer } & - \\ \text { Ammonium citrate } & - \\ \text { Hydrogen sulfide } & - \\ \text { Urease } & - \\ \text { Gelatin liquefaction } & - \\ \text { Growth in KCN medium } & - \\ \text { Phenylalanine deaminase } & - \\ \text { Sodium malonate } & -\end{array}$

Anaerogenic variants are not uncommon.

The contents of the 1950 and 1953 reports on the Escherichia group are reaffirmed.

The differentiation of typical Escherichia cultures from members of other groups of Enterobacteriaceae is not difficult and may be accomplished by utilization of the substrates and tests listed in the definition and in the appended table of biochemical reactions given by Enterobacteriaceae. However, anaerogenic, nonmotile Escherichia biotypes, which do not ferment lactose or do so slowly, occur and such strains of ten are difficult to distinguish from shigellae. Such biotypes of ten may be distinguished from members of the Shigella group 
by means of Christensen's citrate agar, the ninhydrin test of Carlquist, the lysine decarboxylase test (Moeller), or by their reaction in mucate medium (see Appendix for references to these tests). Members of the Shigella group yield negative reactions in all of these tests, whereas members of the Escherichia group usually give positive results.

Since the second report on the Escherichia group was written the number of $O$ antigen groups has been extended to 137, the number of $\mathrm{K}$ antigens to 80 , and the number of $\mathrm{H}$ antigens to 42. Additional $O$ antigen groups, as well as $K$ and $H$ antigens have been characterized but numbers have not been assigned to them as yet. Considerable progress has been made in studies on the serology of the Escherichia group and many individual serotypes have been characterized within the various 0 antigen groups. Work on the preparation of an antigen schema embracing the entire Escherichia group, as it is constituted at present, is in progress, but it will be some time before this can be made generally available.

Recommendations regarding methods for the designation of the $K$ antigens of Escherichia serotypes, and for writing the formulas of the serotypes, were given by Kauffmann, Ørskov, and Ewing (1956).

\section{REFERENCES}

Ewing, W. H., Tatum, H. W., Davis, B. R., and Reavis, R. W. Studies on the serology of the Escherichia coli group. August 1956. CDC Monograph. Communicable Disease Center, Public Health Service, Atlanta, Ga. Kauffmann, F., Orskov, F., and Ewing, W. H. 1956. Internat'l. Bull. Bact. Nomen. Tax. 6:63.

Orskov, F. 1956. Acta Path. Microbiol. Scand. 39:147.

THE KLEBSIELLA GROUP

(Third Report)

\section{Klebsiella Definition}

The Klebsiella group consists of nonmotile, encapsulated bacteria that conform to the definition of the family Entero- 
Page 40

I N T E R N A T I O NAL B U L L E T I N

bacteriaceae, and have the following biochemical characteristics:

$\begin{array}{lc}\text { Gas from glucose } & + \\ \text { Lactose } & + \\ \text { Sucrose } & + \\ \text { Mannitol } & + \\ \text { Dulcitol } & d \\ \text { Salicin } & + \\ \text { Adonitol } & + \\ \text { Inositol } & + \\ \text { Indol } & - \\ \text { Methyl red } & - \\ \text { Voges-Proskauer } & + \\ \text { Ammonium citrate } & + \\ \text { Hydrogen sulfide } & - \\ \text { Urease } & + \\ \text { Gelatin liquefaction } & - \\ \text { Growth in KCN medium } & + \\ \text { Phenylalanine deaminase } & - \\ \text { Sodium malonate } & +\end{array}$

Since the second report on the Klebsiella group was published, additional biochemical tests not included in the definition have been applied which are helpful in the differentiation of Klebsiella strains from other groups. Hormaeche and Munilla (1) found that Klebsiella cultures produced gas promptly from cellobiose whereas Serratia cultures did not. They also found that Klebsiella cultures produced gas from insoluble starch within 4 days, whereas most Cloaca (Aerobacter) cultures did not. The same authors devised a test for urea hydrolysis which was helpful in the differentiation of Klebsiella and Cloaca (Aerobacter) strains. While Klebsiella cultures hydrolyze urea, their urease activity is much less than that of Proteus cultures, so that the two are not likely to be confused. Moeller (2) demonstrated that decarboxylase tests, particularly the test for ornithine decarboxylase, were useful in the differentiation of Klebsiella and Cloaca (Aerobacter) cultures, the latter giving positive tests for ornithine decarboxylase whereas the former did not. These observations were confirmed by Hormaeche and Munilla (4), Ørskov (3) and Edwards, Fife and Ellis (4). The lysine decarboxylase test is promptly positive with Klebsiella cultures but often negative, weak, or delayed with Cloaca (Aerobacter) strains. 
It must be recognized that biochemically aberrant strains occur in the group, the anaerogenic Klebsiella rhinoscleromatis of capsule type 3 being quite unlike the usual strains of Klebsiella pneumoniae in its biochemical properties (Kauffmann, 5). The "ozaenae" strains which occur most frequently in capsule type 4 also possess distinctive biochemical characteristics. While the group is characterized as indol negative and failing to liquefy gelatin, a number of cultures which are indol positive and which liquefy gelatin have been found. In the Klebsiella group there is a rather close correlation between indol production and gelatin liquefaction. Lautrop (6) has pointed out that these indol positive, gelatin positive strains correspond to Bacterium oxytocum of Flügge (1886).

Because of technical difficulties in the recognition of 0 antigens, the organisms still are classified serologically by capsular reactions and 72 capsule types presently are recognized. Five $O$ antigen groups have been demonstrated (Kauffmann, 5; Orskov, 7).

\section{REFERENCES}

1. Internatl. Bull. Bact. Nomen. Tax. 7:1. 1957.

2. Acta Path. et Microbiol. Scand. 25:259. 1954.

3. Acta Path. et Microbiol. Scand. 40:155. 1957.

4. Unpublished data.

5. Acta Path. et Microbiol. Scand. 26:381. 1949.

6. Acta Path. et Microbiol. Scand. $39: 375.1956$.

7. Acta Path. et Microbiol. Scand. $\underline{34}: 145$. 1954.

\section{THE CLOACA (AEROBACTER) GROUP}

(First Report)

\section{Cloaca (Aerobacter) Definition}

The Cloaca (Aerobacter) group consists of motile bacteria that conform to the definition of the family Enterobacteriaceae, and have the following biochemical characteristics:

$\begin{array}{ll}\text { Gas from glucose } & + \\ \text { Lactose } & + \\ \text { Sucrose } & +\end{array}$


Page 42

I N T ER N A T IONAL B ULLETIN

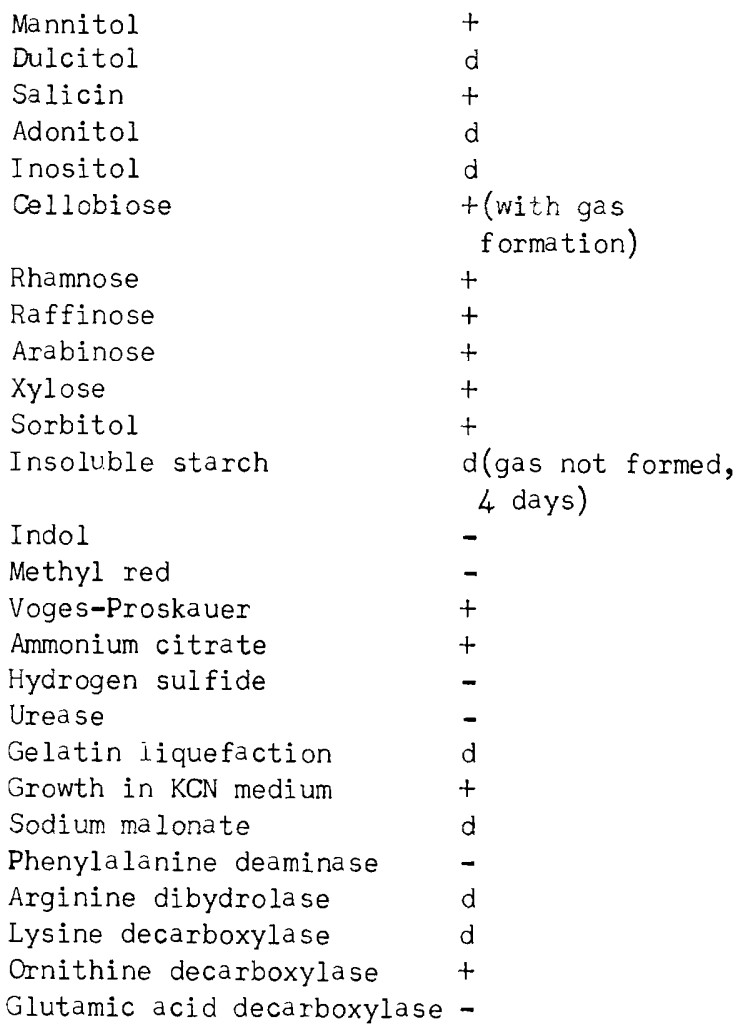

Although these biochemical reactions can be considered as typical of the group there are aberrant cultures, not fermenting lactose, sucrose, rhamnose, sorbitol, raffinose, MR positive, VP, citrate, or KCN negative. Anaerogenic strains also exist.

Two biochemical types can be differentiated. Type A does not generally ferment inositol nor glycerol, and when so doing does not produce gas in four days; it is arginine positive, lysine negative and liquefies gelatin. Type B promptly ferments with gas inositol and glycercl, is arginine negative, lysine positive and about half of the strains do not liquefy gelatin. 
B A C T ERIOLOGICAL NOMENCLA T URE A N D $\quad T \quad A \quad X O N O M Y$

The statement that the group does not split urea is to be understood in the sense that this is so only if special tests for differentiation of Klebsiella and Cloaca (Aerobacter) are used.

Some Klebsialla capsular antigens have been recognized in capsulated strains of the group.

\section{The Starch Test}

$\begin{array}{ll}\text { Beef extract } & 0.5 \mathrm{gm} \text {. } \\ \text { Peptone (Evans) } & 1.0 \mathrm{gm} . \\ \mathrm{NaCl} & 0.5 \mathrm{gm} . \\ \text { Water } & 100 \mathrm{ml} \text {. } \\ \text { Phenol red }(1 / 500) & 0.6 \mathrm{ml} \text {. }\end{array}$

Adjust $\mathrm{pH}$ at $7.2-7.4$. Heat at $120^{\circ} \mathrm{C}$ for 10 minutes, filter, sterilze at $115^{\circ} \mathrm{C}$ for 20 minutes.

To this basic medium $1 \mathrm{gm}$. of insoluble starch is added. To avoid lumps and assure uniformity of the medium this substance is finely ground, added to a small amount of cold water, the mixture stirred and then boiled for 5 minutes. The resulting jelly is incorporated into the medium, this is distributed in sterile tubes $(120 \times 12)$ fitted with gas bells and sterilized at $110^{\circ} \mathrm{C}$ for 15 minutes. The tubes are inoculated with a loopful of a 24 -hour broth culture and observed daily. If on the fourth day there is no visible gas in the bell insert into the medium the red-hot wire loop, in an effort to determine whether dissolved gas is present.

\section{Phenol-red Solution}

Phenol-red

$1 \mathrm{gm}$.

$\mathrm{NaOH} \mathrm{N} / 10$

$40 \mathrm{gms}$.

Distilled water

$460 \mathrm{ml}$.

\section{The Urea Tests}

A) The slow test. (Modification of Christensen medium modified by M. Kristensen)

Bacto peptone $\quad 0.1 \mathrm{gm}$. 
Page 44

I $N$ T ER N A T I ONAL B ULLETIN

$\begin{array}{ll}\mathrm{NaCl} & 0.5 \mathrm{gm} . \\ \mathrm{KH}_{2} \mathrm{PO}_{4} & 0.2 \mathrm{gm} . \\ \text { Cresol-red (0.4\%) } & 2.4 \mathrm{ml} . \\ \text { Distilled water } & 100 \mathrm{ml} .\end{array}$

Boil all the ingredients, adjust carefully $\mathrm{pH}$ to 6.7 , filter and sterilize at $115^{\circ} \mathrm{C}$ for 20 minutes. Add $0.2 \mathrm{gm}$. urea Seitz filtered or chloroform sterilized. Distribute in sterilized tubes $(120 \times 12)$. Inoculate from a 24 -hour broth culture and observe for four days, when positive reactions will show a rediish-purple color. Exact adjustment of the medium's reaction is essential, as if it is higher than indicated many Cloaca (Aerobacter) cultures will be positive, and if lower some Klebsialla will be negative.

\section{Cresol-red Solution}

$\begin{array}{lr}\text { Cresol-red } & 0.1 \mathrm{gm} . \\ \mathrm{NaOH} \mathrm{N} / 50 & 13.1 \mathrm{ml} . \\ \text { Distilled water } & 237.0 \mathrm{ml} \text {. }\end{array}$

B) The quick test

$\begin{array}{ll}\text { Urea } & 2.0 \mathrm{gms} . \\ \begin{array}{ll}\text { Cresol-red solution } & 2.0 \mathrm{ml} . \\ (0.4 \%) & \\ \text { Distilled water } & 100 \mathrm{ml} .\end{array}\end{array}$

Add monopotassium phosphate to a final concentration of $1 / 10,000$, and distribute in hemolysis tubes $1 \mathrm{ml}$. each. No sterilization is needed. Inoculate with two heavy loopfuls of a 24-hour agar culture and incubate for two hours in the water bath at $45^{\circ}-50^{\circ} \mathrm{C}$. Positive reactions will show a reddish-purple color.

Lactose agar must not be used for growing bacteria for the test, or most Cloaca (Aerobacter) cultures will be positive, and the same happens when some brands of peptone are used. Good results are obtained with agar prepared with beef extract, $0.5 \mathrm{gm} ., \mathrm{NaCl} 0.5 \mathrm{gm}$., Evans peptone $1 \mathrm{gm}$, agar $2 \mathrm{gms}$, for $100 \mathrm{ml}$. water, and with $\mathrm{pH}$ adjusted at 7-7.2. 
B A C T ERIOLOGICAL NOMENCLATURE $A N D$ T A X O N O M Y

\section{REFERENCES}

Edwards, P.R. and Fife, M.A. Jour. Bact. 70:382. 1955. Moeller, V. Acta Path. et Microbiol. Scand. 36:158. 1955. Kauffmann, F. Acta Path. et Microbiol. Scand. 39:85. 1956. Hormaeche, E. and Munilla, M. Internatl. Bull. Bact. Nomen.

Tax. 7:1. 1957.

\section{ADDENDUM:}

Drs. Edwards, Ewing, and Hormaeche prefer the name, Aerobacter, for the above-mentioned group and recognize at least two subdivisions corresponding to Aerobacter aerogenes and Aerobacter cloacae.

\section{THE HAFNIA GROUP \\ (Provisiona l) \\ Hafnia Definition}

The Hafnia group consists of motile bacteria that conform to the definition of the family Enterobacteriaceae, and have the following biochemical characteristics:

$\begin{array}{lcc} & 37^{\circ} \mathrm{C} & 22^{\circ} \mathrm{C} \\ \text { Gas from glucose } & & + \\ \text { Lactose } & \mathrm{d} & - \text { or } \mathrm{x} \\ \text { Sucrose } & \text { or } \mathrm{x} & \mathrm{x} \\ \text { Mannitol } & + & + \\ \text { Dulcitol } & - & - \\ \text { Salicin } & \mathrm{d} & \mathrm{d} \\ \text { Adonitol } & - & - \\ \text { Inositol } & - & - \\ \text { Indol } & - & - \\ \text { Methyl red } & + & + \\ \text { Voges-Proskauer } & \mathrm{d} & + \\ \text { Ammonium citrate } & \mathrm{d} & (+) \\ \text { Hydrogen sulfide } & - & - \\ \text { Urease } & - & - \\ \text { Gelatin liquefaction } & - & + \\ \text { Growth in KCN medium } & + & \end{array}$


Phenylalanine deaminase Sodium malonate $\bar{d} \quad \bar{d}$

Moeller (1954) gave the name Hafnia to a group of bacteria that were delineated and characterized biochemically during the examination of cultures variously designated as "paracolon aerobacter", "Paracolobactrum aerogenoides", and "intermediate paracolon" bacteria. Subsequently, it was learned that the Hafniae were identical with biotype 32011 of the second division of "paracolon Aerobacter" described by Stuart et al. (1943). Also, Bacillus asiaticus and B. asiaticus, var. mobilis (Castellani, 1906) and B. paratyphi alvei (Bahr, 1919) were found to be Hafnia strains. However, it should be noted that Moeller (1954) mentioned that one culture labeled B. asiaticus var. mobilis was not a member of the Hafnia group.

Members of the Hafnia (32011) group compose a biotype or group of biotypes, which are somewhat similar to other VogesProskauer positive Enterobacteriaceae. However, they may be differentiated by the effect of temperature of incubation on their biochemical activities, their failure to ferment lactose or failure to ferment it rapidly, by their failure to ferment sorbitol, by failure to liquefy gelatin, and by other biochemical reactions.

Deacon (1952) and Eveland and Faber (1953) have studied members of the 32011 (Hafnia) biotype and in each of these investigations a number of $\mathrm{O}$ and $\mathrm{H}$ antigens were established. However, little is known of the antigenic relationship of members of this group of microorganisms to other Voges-Proskauer positive Enterobacteriaceae.

The existence of the biotype or group of biotypes that are named Hafnia herein is well recognized and accepted, but the status of the group itself is undecided at present. That is, the question of whether these bacteria should be considered as a special biotype within an existing group or given group status must be given further study and consideration.

\section{REFERENCES}

Deacon, W. E. 1952. Proc. Soc. Expt. Biol. and Med. 81:165. Eveland, W. C. and Jaber, J. E., Jr. 1953. Jour. Infect. Dis. $93: 226$. 
B A C I ERIOLOGICAL NOMENCLATURE A N D T T A X O N O M Y

Moeller, V. 1954. Acta Path. et Microbiol. Scand. 34:145. Stuart, C. A., Wheeler, K. M., Rustigian, R., and Zimmermann, H. 1943. Jour. Bact. 45:101.

\section{ADDENDUM}

Dr. Cowan requested that the following opinion be added to the Hafnia (provisional) Group report.

"Only certain strains labelled B. asiaticus by Castellani belong to the Hafnia group; these are ones distributed in the last few years. Strains received from Castellani in 1924 and 1938 are not members of the Hafnia group.

The important point is that Castellani's description of B. asiaticus does not agree with that of the Hafnia group. In the absence of type strains designated by Castellani at the time he named the organism, his description determines what are the characters of $\underline{B}$. asiaticus and a neotype which differed significantly from that description would not be acceptable.

In my opinion B. asiaticus does not enter into any synonymy of the Hafnia group."

\section{THE SERRATIA GROUP \\ (First Report) \\ Serratia Definition}

The Serratia group consists of motile bacteria that conform to the definition of the family Enterobacteriaceie, some strains produce pink or red pigment and the bacteria have the following biochemical characteristics:

$\begin{array}{ll}\text { Gas from glucose } & \mathrm{d} \\ \text { Lactose } & - \text { (or }+ \text { weak and } \\ & \\ \text { Sucrose } & + \text { delayed }) \\ \text { Mannitol } & + \\ \text { Dulcitol } & - \\ \text { Salicin } & + \\ \text { Adonitol } & d\end{array}$




$\begin{array}{lc}\text { Inositol } & \mathrm{d} \\ \text { Indol } & - \\ \text { Methyl red } & - \\ \text { Voges-Proskauer } & + \\ \text { Ammonium citrate } & + \\ \text { Hydrogen sulfide } & - \\ \text { Urease } & - \\ \text { Gelatin liquefaction } & + \\ \text { Growth in KCN medium } & + \\ \text { Phenylalanine deaminase } & - \\ \text { Sodium malonate } & -\end{array}$

When gas is formed the volumes are small, 5 per cent or less. Acid production from lactose within 1 day is uncommon but weak, delayed reactions are often observed. Hydrogen sulfide is not formed on triple sugar iron or lead acetate agars in the usual incubation periods but weak, delayed ( 5 to 7 days) reactions are obtained with many cultures.

Members of the Serratia group may be separated from Klebsiella on the basis of their motility, failure to utilize malonate, slowness and reluctance to ferment lactose, slight, delayed, or negative urease reactions, and by the small volumes of gas produced by aerogenic cultures. They may be distinguished from members of the Aerobacter (Cloaca) group by their. rapid liquefaction of gelatin, reluctance to produce acid from lactose, failure to utilize malonate, and by the small volumes of gas produced from fermentable substrates. The majority of Serratia cultures produced only delayed, slightly acid reactions in cellobiose broth and gas was not formed. Aerobacter (Cloaca) strains generally produce acid and gas from cellobiose within 24 hours' incubation. Serratia strains may be differentiated from those belonging to the Hafnia group by negative methyl red tests at $37^{\circ} \mathrm{C}$, by gelatin liquefaction, and by the small volumes of gas produced by aerogenic strains. Sorbitol fermentation also served to distinguish between members of these two groups, since the majority of Serratia strains produced acid from this substrate whereas known members of the Hafnia group did not utilize it. When present, pink or red pigment aided in the differentiation of Serratia cultures.

The above-mentioned comments, as well as the definition of the Serratia group, were based upon results obtained in the examination of 50 strains, all except two of which were isolated during the past few years (Davis, Ewing, and Reavis, 1957). A summary of the biochemical reactions with these 
cultures is given in the appended chart. These strains were also employed in the serological studies mentioned below.

In addition to the above-mentioned 50 strains, 57 cultures from various type culture collections were examined (Davis, Reavis, and Ewing, 1957). When received the majority of these cultures was labeled $\underline{S}$. marcescens but several were listed under other specific epithets. It should be noted that the same strain was received from two or more type culture collections in many instances and hence there were many duplications among the 57 cultures. Also, many of the strains were very old, having been in the collections for many years. The majority of the cultures gave biochemical reactions similar to those given by the 50 more recently isolated strains mentioned above. However, a few were aberrant in several respects and probably should be excluded from the group. Also, a few cultures, some of which were aerogenic and some of which were anaerogenic, were MR positive and $V-P$ negative. Such cultures were few in number but gave biochemical reactions similar to those given by typical Serratia cultures except for the reversal in the MR and V-P repctions. Therefore, it was obvious that the occasional occurrence of MR positive, $V-P$ negative Serratia must be recognized since a few such cultures were identified in the collection.

Six 0 antigen groups were established within the Serratia group by Davis and Woodward (1957) and Davis, Ewing, and Reavis (1957) were able to determine the 0 group of 47 of the 50 more recently isolated strains mentioned above and listed in the summary of biochemical reactions. Several $\mathrm{H}$ antigens also were delineated (unpublished data). Preliminary examinations of the 0 antigens of the 57 cultures from type culture collections indicated that at least 40 belonged to one or another of the six delineated 0 antigen groups. The 0 antigen group of several of the cultures could not be determined because of roughness and nine of the undetermined strains were biochemically aberrant.

\section{REFERENCES}

Davis, B.R. and Woodruff, J.M. 1957. Canad. J. Microbiol. 3:391. Davis, B. R., Ewing, W. H., and Reavis, R. W. 1957. Internatl. Bull. Bact. Nomen. Tax. 7:151.

Davis, B. R., Reavis, R. W., and Ewing, W. H. 1957. Unpublished data. 
Page 50

I N T ER NATIONAL BULLET I N

Summary of results of biochemical tests with fifty Serratia
group cultures

Test

Glucose

Gas

Lactose

Sucrose

Maltose

Mannitol

Dulcitol

Rhamnose

Arabinose

Inositol

Xylose

Raffinose

Sorbitol

Salicin

Adonitol

Trehalose

Cellobiose

Motility

Simmons citrate

Christensen ${ }^{8}$ s citrate

Urease

Indol

Methyl red

Voges-Proskauer

Hydrogen sulfide (TSI)

Nitrate reduction

Ammonla glucose agar

Gelatin (220 C)

Phenylalanine deaminase

Malonate

Lysine decarboxylation ${ }^{*}$

KCN

Pigment

\section{No. +}

50

32

1

50

50

50

0

0

1

31

3

1

48

50

38

50

$4 w$

50

50

50

0

0

0

50

0

50

50

49

5 w

0

$49 w$

48

16
No. + delayed No. -

0

0

18

20

0

0

0

50

50

49

3

31

48

2

0

4

0

2

0

0

0

32

50

50

0

24

0

0

1

45

50

1

2

34

w - weak; indicates slight reactions.

* - Gas was not formed from cellobiose by any culture.

**- Ninhydrin method of Carlquist.

1 - From Davis et al. 1957, modified. 
B A C I ERIOLOGICAL NOMENCLATURE A N D T A X X O N O M Y

THE PROVIDENCE GROUP

(Second Report)

Providence Definition

The Providence group consists of motile bacteria that conform to the definition of the family Enterobacteriaceae, and have the following biochemical characteristics:

$\begin{array}{lc}\text { Gas from glucose } & d \\ \text { Lactose } & - \\ \text { Sucrose } & d \\ \text { Mannitol } & d \\ \text { Dulcitol } & - \\ \text { Salicin } & - \\ \text { Acionitol } & d \\ \text { Inositol } & d \\ \text { Indol } & + \\ \text { Methyl red } & + \\ \text { Voges-Proskauer } & - \\ \text { Ammonium citrate } & + \\ \text { Hydrogen sulfide } & - \\ \text { Urease } & - \\ \text { Gelatin liquefaction } & - \\ \text { Growth in KCN medium } & + \\ \text { Phenylalanine deaminase } & + \\ \text { Sodium malonate } & -\end{array}$

The recommendations and antigenic schema given in the first report on the Providence group (see 1953 Subcommittee Report) are reaffirmed.

Members of the Providence group may be differentiated from members of the Salmonella and Arizona groups on the basis of indol production, fermentation of sucrose and adonitol by many strains, and failure to produce hydrogen sulfide. They may be differentiated from Citrobacter cultures by means of indol production, fermentation of adonitol by many strains, failure to produce acid from lactose, and failure to form hydrogen sulfide. Providence group cultures may be distinguished from members of the Shigella group by means of their utilization of citrate, their motility, and by their fermentation of adonitol, inositol, or sucrose. They are differentiated from 
Klebsiella, Aerobacter (Cloaca), Hafnia, and Serratia by their reactions in the $M R$ and $V-P$ tests, by indol production and by failure to ferment lactose. Further, members of the Providence group produce phenylpyruvic acid from phenylalanine, whereas members of the above-mentioned groups do not. Proteus cultures also deaminate phenylalanine to phenylpyruvic acid, but Proteus cultures hydrolyze urea whereas Providence strains do not. Also, members of the Providence group do not liquefy gelatin or produce hydrogen sulfide, whereas two species of Proteus (P. vulgaris and P. mirabilis) do so.

Providence group cultures may be divided into two principal biogroups, each of which is further divisible into a number of biotypes (Ewing, Tanner, and Dennard, 1954). The biogroups may be differentiated and the biotypes that occurred most commonly may be allocated to the appropriate biogroup on the basis of the following:

\section{Biogroup 1 Biogroup 2}

$\begin{array}{lcc}\text { Gas from glucose } & + & - \\ \text { Adonitol } & + & - \\ \text { Inositol } & - & +\end{array}$

Since the antigenic schema contained in the first report on the Providence group was written the number of 0 antigen groups has been extended to 62 , the number of $\mathrm{H}$ antigens to 30 , and the number of known serotypes to 156.

As mentioned in the introduction to this Report, it is recommended that the Providence group be maintained as a separate entity until international agreement is reached regarding the taxonomy and nomenclature of the Proteus and Providence groups.

\section{REFERENCE}

Ewing, W. H., Tanner, K. E., and Dennard, D. A. 1954. Jour. Infect. Dis., 94:134. 
Page 53

B A C TERIOLOGICAL NOMENCIATURE AND I AXONOMY

RECOMMENDED BIOCHEMICAL METHODS FOR GROUP DIFFERENTIATION WITHIN THE ENTEROBACTERIACEAE

$\begin{array}{cr}\text { Recommended } & \text { Alternate } \\ \text { Test No. } & \text { Test No. }\end{array}$

Gas from glucose

Lactose

Sucrose

Mannitol

Dulcitol

Salicin

Adonitol

Inositol

Indol

Methyl Red

Voges-Proskauer

Annonium Citrate

Hydrogen Sulfide

Urease

Gelatin

KCN

1

2

1

1

2

1

2

1

2

2

12

12

12

34

5

67

8

910

$11 \quad 12$

$13 \quad 14$

Motility

15

16

17

Phenylalanine

18

Ma lonate

20

19

N.B.

It will be noted that the temperature of incubation reccommended for the majority of the tests is $37^{\circ} \mathrm{C}$. However, if preliminary examinations indicate that a culture may be a member of the Hafnia group, tests should be repeated and incubated at $20^{\circ}$ to $22^{\circ} \mathrm{C}$. 
Page 54

Test No. 1

Broth base for carbohydrates: Liebig's meat extract broth, $\mathrm{pH} 7.4$.

$\begin{array}{lr}\text { Meat extract } & 5 \mathrm{gms} . \\ \text { Peptone } & 10 \mathrm{gms} \text {. } \\ \text { Sodium chloride } & 3 \mathrm{gms} . \\ \text { Dibasic sodium phosphate } & 2 \mathrm{gms} \text {. } \\ \text { Indicator solution } & 12 \mathrm{ml} . \\ \text { Distilled water } & 1000 \mathrm{ml} \text {. }\end{array}$

Liebig's, Lemco, Difco, or other comparable meat extract and Orthana, Bacto, Evans, or other similar peptone may be used.

Indicator solution

$\begin{array}{lr}\text { Bromthymol blue } & 1 \mathrm{gm} \text {. } \\ 1 / 10 \text { Normal NaOH } & 25 \mathrm{ml} \text {. } \\ \text { Distilled water } & 475 \mathrm{ml} \text {. }\end{array}$

Add 0.5 per cent of test substance, tube with inverted insert tubes, and sterilize at $121^{\circ} \mathrm{C}$ for 15 minutes. Glucose, mannitol, adonitol, inositol, and salicin may be added to the medium prior to sterilization. Disaccharides such as lactose and sucrose should be sterilized by filtration and added to previously sterilized basal medium.

Inoculation: Inoculate lightly from a young (16-20 hrs. incubation) agar slant culture.

Incubation: $370 \mathrm{C}$. Negative tests should be observed for 30 days.

Test No. 2

Fermentation broth base. Alternate method for carbohydrate tests.

$\begin{array}{lr}\text { Peptone } & 10 \mathrm{gms} . \\ \text { Meat extract } & 3 \mathrm{gms} \text {. } \\ \text { Sodium chloride } & 5 \mathrm{gms} \text {. } \\ \text { Andrade's indicator } & 10 \mathrm{ml} \text {. } \\ \text { Distilled water } & 1000 \mathrm{ml} \text {. }\end{array}$


Liebig's, Lemco, Difco, or other comparable meat extract and Orthana, Bacto, Evans, or other similar peptone may be used.

Andrade's Indicator

$\begin{array}{lr}\text { Distilled water } & 100 \mathrm{ml} . \\ \text { Acid fuchsin } & 0.5 \mathrm{gm} . \\ \text { Sodium hydroxide }(1 \mathrm{~N}) & 16 \mathrm{ml} .\end{array}$

The fuchsin is dissolved in the distilled water and the sodium hydroxide is added. If, after several hours, the fuchsin is not sufficiently decolorized add an additional 1 or " $\mathrm{ml}$. of alkali. The dye content of different samples of acid fuchsin varies quite widely and the amount of alkali which should be used with any particular sample usually is specified on the label. The reagent improves somewhat on aging and should be prepared in sufficiently large amount to last for several years. The indicator is used in amounts of $10 \mathrm{ml}$. per liter of medium.

Adjust reaction to $\mathrm{pH} 7 \cdot 1-7.2$. Tube with inverted insert tubes and sterilize in autoclave at $15 \mathrm{lbs}$. for 15 minutes. Fermentable substances may be sterilized by filtration of 5 or 10 per cent solution and added aseptically to the base in sufficient amount to make a final concentration of 0.5 or 1.0 per cent.

Inoculation and incubation: as given under Test No. 1.

$$
\text { Test No. } 3
$$

Medium for indol tests. Peptone water.

$\begin{array}{lr}\text { Peptone } & 20 \mathrm{gms} \text {. } \\ \text { Sodium chloride } & 5 \mathrm{gms} \text {. } \\ \text { Distilled water } & 1000 \mathrm{ml} \text {. }\end{array}$

Leave reaction unadjusted and sterilize at $121^{\circ} \mathrm{C}, 15$ minutes. Two per cent Bacto peptone may be used or, if desired other comparable peptones such as Evans, Merck, or Vaillant No. 5. One per cent tryptone also is satisfactory.

Inoculation: Inoculate lightly from a young agar slant culture. 
Incubation: $370 \mathrm{C}, 40$ to 48 hours. Test with Kovacs' reagent. Add about $0.5 \mathrm{ml}$. of reagent, shake tube gently. A deep red color develops in the presence of indol.

\section{$\underline{\text { Kovacs' reagent }}$}

$$
\begin{array}{lr}
\text { Pure Amyl or isoamyl alcohol } & 150 \mathrm{ml} \text {. } \\
\text { Paradimethylaminobenzaldehyde } & 10 \mathrm{gms} \text {. } \\
\text { Concentrated pure hydrochloric acid } & 50 \mathrm{ml} .
\end{array}
$$

Dissolve aldehyde in alcohol and then slowly add acid. The dry aldehyde should be light in color. Kovacs' reagent should be prepared in small quantities and stored in the refrigerator when not in use.

Remarks on indol test (applicable to both Test No. 3 and No. 4). Tests for indol production may be made after 24 hours incubation, but if this is to be done, one or two $\mathrm{ml}$. of culture should be removed aseptically from the tube and the test made on this sample. If the test is negative, the remaining portion of the peptone water culture should be reincubated for an additional 24 hours.

$$
\text { Test No. } 4
$$

Medium for indol tests. Alternate method.

$$
\begin{array}{ll}
\text { Casein digest broth } & 1000 \mathrm{ml} \text {. } \\
\text { Tap water } & 2000 \mathrm{ml} .
\end{array}
$$

Sterilize at $121^{\circ} \mathrm{C}, 15$ minutes.

The casein digest broth is prepared in the manner given by Kristensen et al., Brit. J. Exper. Path. 6:291. 1925.

(A medium prepared with 1.5 per cent Irypticase (BBL), Casitone (Difco) or other commercially available product that gives results comparable to those obtained with the medium listed in test No. 3 may be used. If a casein digest is used it should be an enzymatic digest - not an acid one).

Inoculation and Incubation: as given in Test No. 3. Test with Ehrlich-Boehme reagent. Carefully add about $0.5 \mathrm{ml}$. of reagent. Do not shake tube. A rose purple color develops in the presence of indol. 
B A C T ER I OLOGICA L N OMENCLA TURE A N D T A X O N O M Y

Ehrlich-Boehme reagent.

Paradimethylaminobenzaldehyde

$8 \mathrm{gms}$.

95 to 96 per cent ethyl alcohol $\quad 760 \mathrm{ml}$.

Concentrated pure hydrochloric acid $160 \mathrm{ml}$.

Test No. 5

\section{The Methyl Red test.}

Buffered peptone glucose broth. Three modifications of the Clark and Lubs formula are listed below. Any of these may be used for both the Methyl Red and Voges-Proskauer tests. It is understood that 0.5 per cent Evans peptone may be substituted in the formulas.
A. Dibasic potassium phosphate
$0.5 \mathrm{gm}$.
Peptone, Orthana special
$0.5 \mathrm{gm}$.
Glucose
$0.5 \mathrm{gm}$.
Distilled water
$100 \mathrm{ml}$.

Mix dibasic potassium phosphate, peptone, and distilled water, heat to boiling and then filter. Sterilize at $121^{\circ} \mathrm{C}, 15$ minutes. Add $0.5 \mathrm{gm}$. of glucose. Tube and boil for $10 \mathrm{~min}$ utes.

$$
\begin{array}{lr}
\text { B. MR-VP medium (BBL) } & \\
\text { Dipotassium phosphate } & 5.0 \mathrm{gms} \text {. } \\
\text { Polypeptone } & 7.0 \mathrm{gms} \text {. } \\
\text { Glucose } & 5.0 \mathrm{gms} \text {. } \\
\text { Distilled water } & 1000 \mathrm{ml} .
\end{array}
$$

Suspend ingredients in water and heat slightly to dissolve them. Tube and sterilize at $118^{\circ} \mathrm{C}$ to $121^{\circ} \mathrm{C}$ for 15 minutes.

$$
\begin{array}{lr}
\text { C. MR-VP medium (Difco) } & \\
\text { Buffered peptone } & 7 \mathrm{gms} . \\
\text { Glucose } & 5 \mathrm{gms} . \\
\text { Dipotassium phosphate } & 5 \mathrm{gms} \text {. } \\
\text { Distilled water } & 1000 \mathrm{ml} \text {. }
\end{array}
$$

Inoculation: Inoculate lightly from a young agar slant culture. 
Incubation: $370 \mathrm{C}$, for 48 hours to 5 days. Tests should not be performed with cultures incubated less than 48 hours but $48 \mathrm{hrs}$. is sufficient for the majority of cultures. However, if the results of tests made at $48 \mathrm{hrs}$. are equivocal, the tests should be repeated with cultures that have been incubated for 4 or 5 days.

Test reagent:

$$
\begin{array}{ll}
\text { Methyl Red } & 0.1 \mathrm{gm} . \\
\text { Ethyl a lcohol } & 300 \mathrm{ml} . \\
& \text { (95 to 96\%) }
\end{array}
$$

Dissolve dye in the alcohol and then add sufficient distilled water to make $500 \mathrm{ml}$. Use 5 or 6 drops of reagent per $5 \mathrm{mil}$. of culture. Reactions are read immediately. Positive tests are bright red, weakly positive tests are red-orange and negative tests are yellow.

Test No. 6

Voges-Proskauer test. Test for the production of acetylmethylcarbinol (acetoin) and 2,3 - butyleneglycol.

Buffered peptone glucose broth. The same medium used in Test No. 5, may be used for the $V-P$ test.

Inoculation: as in Test No. 5 .

Incubation: $377^{\circ} \mathrm{C}, 48 \mathrm{hrs}$.

Test reagent (OMeara)

$\begin{array}{lr}\text { Potassium hydroxide } & 40 \mathrm{gms} . \\ \text { Creatine } & 0.3 \mathrm{gm} . \\ \text { Distilled water } & 100 \mathrm{ml} .\end{array}$

Dissolve the alkali in distilled water and add creatine. Use the reagent in the proportion of $0.1 \mathrm{ml}$. per $1.0 \mathrm{ml}$. of culture. Place tubes in a water bath (about $48^{\circ}$ to $50^{\circ} \mathrm{C}$ ) for 2 hrs. or at $370 \mathrm{C}$ for $4 \mathrm{hrs}$. Aerate by shaking the tubes. A positive $\mathrm{V}-\mathrm{P}$ test is indicated by the development of a delicate eosinpink color. 
B ACTERIOLOGICAI NOMENCLATURE A N D I A X O NOMY

Test No. 7

Voges-Proskauer test. Alternate method.

Buffered peptone glucose broth, as used in Test No. 5 or 6 .

Inoculation: same as Test Nos. 5 and 6.

Incubation: $370 \mathrm{C}, 4$ days.

Test reagent (Barritt)

One $\mathrm{ml}$. of 6 per cent alcohol solution of alphanapthol and $0.4 \mathrm{ml}$. of 40 per cent potassium hydroxide are added to $2 \mathrm{ml}$. of broth culture. Positive reactions occur at once or within a few minutes. The Barritt test is somewhat more sensitive than the O'Meara method.

Test No. 8

Ammonium citrate medium. Test for the utilization of sodium citrate and ammonium salts.

$\begin{array}{ll}\text { Sodium chloride } & 5.0 \mathrm{gms} \text {. } \\ \text { Magnesium sulfate } & 0.2 \mathrm{gm} . \\ \text { Ammonium dihydrogen phosphate } & 1.0 \mathrm{gm} . \\ \text { Dipotassium phosphate } & 1.0 \mathrm{gm} . \\ \text { Sodium citrate } & 5.0 \mathrm{gms} \text {. } \\ \text { Agar (washed vigorously } & 20.0 \mathrm{gms} \text {. } \\ \quad \text { for } 3 \text { days) } & \end{array}$

Add $40 \mathrm{ml}$. of 1:500 bromthymol blue indicator solution. (See Test No. 1)

Sterilize at $121^{\circ} \mathrm{C}, 15$ minutes and slant so as to obtain a 1 inch butt and 1-1/2 inch slant.

Inoculation: Prepare a saline suspension from a young agar slant culture and inoculate the slant of the medium with a straight wire from the saline suspension. If desired, the butt of the medium may be stabbed.

Incubation: $37^{\circ} \mathrm{C}$ for 4 days. 
Page 60

The above-mentioned medium is available from several commercial sources under the name of Simmons' citrate agar. These preparations are quite satisfactory.

Test No. 9

Hydrogen sulfide production

Ferrous chloride gelatin

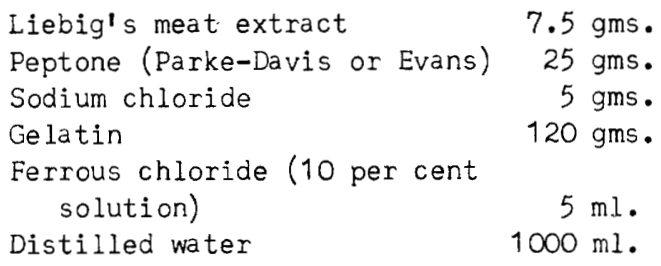

The gelatin medium is boiled and the freshly prepared 10 per cent solution of ferrous chloride immediately added. The medium is tubed in narrow tubes and the tubes are placed in cold water to cool. The tubes are sealed with cork stoppers that have been soaked in hot paraffin.

Inoculation: Inoculate by making a stab into the depths of the medium column.

Incubation: $20^{\circ} \mathrm{C}$. Observe daily for at least 7 days for blackening caused by hydrogen sulfide production.

(This same medium is used for the determination of gelatin liquefaction and hence is actually observed for a much longer period. See Test No. 13).

Test No. 10

Hydrogen sulfide production. Alternate method.

Iriple sugar iron agar (a modification of Kligler's iron agar).

$\begin{array}{lr}\text { Beef extract } & 3 \mathrm{gms} . \\ \text { Yeast extract } & 3 \mathrm{gms} . \\ \text { Bacto peptone } & 15 \mathrm{gms} \text {. } \\ \text { Froteose peptone, Difco } & 5 \mathrm{gms} . \\ \text { Lactose } & 10 \mathrm{gms} . \\ \text { Sucrose } & 10 \mathrm{gms} .\end{array}$


BACIERIOLOGICAL NOMENCLATURE A N D T A X O NOMY

$\begin{array}{lr}\text { Glucose } & 1 \mathrm{gm} . \\ \text { Ferrous sulfate } & 0.2 \mathrm{gm} . \\ \text { Sodium chloride } & 5 \mathrm{gms} . \\ \text { Sodium thiosulfate } & 0.3 \mathrm{gm} . \\ \text { Agar } & 12 \mathrm{gms} . \\ \text { Phenol red } & 0.024 \mathrm{gm} . \\ \text { Distilled water } & 1000 \mathrm{ml} .\end{array}$

Polypeptone (BBL) or Evans peptone may be substituted for the Bacto peptone and proteose peptone in the formula given above.

After sterilization at $121^{\circ} \mathrm{C}, 15$ minutes, the medium is slanted with a deep butt (1 inch butt, 1.5 inch slant).

Inoculation: The butt of the medium is stabbed and the slant is streaked.

Incubation: $370 \mathrm{C}$, observe daily for 5 to 7 days for blackening caused by hydrogen sulfide production.

Remarks about tests for hydrogen sulfide production. If highly sensitive methods are used, hydrogen sulfide production can be demonstrated in cultures that belong to most groups of Enterobacteriaceae and it seems probable that all Enterobacteriaceae produce varying quantities of hydrogen sulfide from inorganic or organic substances. However, for a hydrogen sulfide test to be of value in group differentiation within the Enterobacteriaceae it must be poised at a certain definite level of sensitivity. The media listed above (Tests Nos. 9 and 10) are poised at such a level and thus may be used for group differentiation. Although methods which utilize lead acetate paper strips suspended over peptone water cultures may be of value in intragroup differentiation witnin certain groups, these methods are of no value in intergroup differentiation and cannot be recommended for the latter purpose.

Test No. 11

Test for production of urease.

Christensen's urea agar

Peptone

$1 \mathrm{gm}$.

Sodium chloride

5 gms. 
Page 62

$\begin{array}{lc}\text { Glucose } & 1 \mathrm{gm} . \\ \text { Monobasic potassium phosphate } & 2 \mathrm{gms} . \\ \text { Phenol red } & 0.012 \mathrm{gm} . \text { ( } 6 \\ & \mathrm{ml} \text {. of } 1: 500 \text { solution) } \\ \text { Agar } & 20 \mathrm{gms} . \\ \text { Distilled water } & 1000 \mathrm{ml} .\end{array}$

Adjust to pH 6.8 to 6.9

Bacto, Evans, or other comparable peptone may be used. After sterilization at $121^{\circ} \mathrm{C}$ for 15 minutes, the basal medium is cooled at $50-55^{\circ} \mathrm{C}$ and then sufficient 20 per cent urea solution (Seitz filtered) is added to give a final concentration of 2 per cent. Then the medium is slanted with a deep butt. This medium may be employed in fluid form if desired, by omitting the agar.

Inoculation: The medium is inoculated heavily over the entire surface of the slant.

Incubation: $370 \mathrm{C}$. Examine at 2 hrs., $4 \mathrm{hrs}$. , and after overnight incubation. Negative tubes should be observed daily for 4 days. Urease positive cultures produce an alkaline reaction in the medium evidenced by a red color.

\section{Test No. 12}

Rapid urease test. Alternate method.

$\begin{array}{lr}\text { Yeast extract } & 0.1 \mathrm{gm} . \\ \text { Monobasic potassium phosphate } & 0.091 \mathrm{gm} . \\ \text { Dibasic sodium phosphate } & 0.095 \mathrm{gm} . \\ \text { Urea } & 20 \mathrm{gms} . \\ \text { Phenol red } & 0.01 \mathrm{gm} . \\ \text { Distilled water } & 1000 \mathrm{ml} .\end{array}$

This medium is Seitz filtered and tubed in sterile tubes in $3 \mathrm{ml}$. amounts. The basal medium may be made up in $900 \mathrm{ml}$. of distilled water and sterilized at $121^{\circ} \mathrm{C}, 15$ minutes. After cooling $100 \mathrm{ml}$. of 20 per cent urea solution is added and the medium tubed in sterile tubes in $3 \mathrm{ml}$. amounts.

Inoculation: Three loopfuls ( $2 \mathrm{~mm}$. loop) from an agar slant culture are inoculated into a tube of medium and the tube is shaken to suspend the bacteria. 
B AC TER I OLOGICA L NOMENCLA T URE A N D I A X O NOMY

Incubation: Tests are incubated in a water bath at $370 \mathrm{C}$ and the results are read after 10 minutes, 60 minutes, and 2 hrs.

$$
\text { Test No. } 13
$$

\section{Gelatin liquefaction}

The same tube of ferrous chloride gelatin medium used for the determination of hydrogen sulfide production (Test No. 9) may be observed for gelatin liquefaction. Tubes should be incubated at $20^{\circ} \mathrm{C}$ for 30 days.

$$
\text { Test No. } 14
$$

Gelatin liquefaction. Alternate method.

Nutrient gelatin

$\begin{array}{lr}\text { Beef extract } & 3 \mathrm{gms} . \\ \text { Peptone } & 5 \mathrm{gms} . \\ \text { Gelatin } & 120 \mathrm{gms} . \\ \text { Distilled water } & 1000 \mathrm{ml} \text {. }\end{array}$

Polypeptone (BBL), Bacto, Evans, Parke-Davis, or other comparable peptone may be used. Sterilize at $121^{\circ} \mathrm{C} 12$ minutes.

Inoculation: Inoculate by stabbing the medium with a wire, using inoculum from an agar slant culture.

Incubation: $20^{\circ} \mathrm{C}, 30$ days.

Test No. 15

Potassium cyanide (KCN) test. Test for growth in the presence of $\mathrm{KCN}$.

$\begin{array}{lr}\text { Peptone, Orthana special } & 10 \mathrm{gms} \text {. } \\ \text { Sodium chloride } & 5 \mathrm{gms} \text {. } \\ \begin{array}{l}\text { Monobasic potassium } \\ \text { phosphate }\end{array} & 0.225 \mathrm{gm} \text {. } \\ \begin{array}{l}\text { Dibasic sodium phosphate } \\ \text { Distilled water }\end{array} & 10.64 \mathrm{gms} \text {. } \\ \text { Adjust pH to } 7.6 & \end{array}$


Page 64

The basal medium is sterilized at $121^{\circ} \mathrm{C}$, 15 minutes, then refrigerated until thoroughly chilled. To the cold medium is added $15 \mathrm{ml}$. of 0.5 per cent $\mathrm{KCN}$ solution $(0.5 \mathrm{gms}$. KCN dissolved in $100 \mathrm{ml}$. sterile distilled water). The medium is then tubed in approximately $1.0 \mathrm{ml}$. amounts in sterile tubes $(12 \times 150 \mathrm{~mm}$. or $10 \times 100 \mathrm{~mm}$.) and stoppered quickly with corks sterilized by heating in paraffin. The medium in such tubes can be stored safely for 2 weeks at $4^{\circ} \mathrm{C}$.

It has been found that 0.3 per cent Bacto Proteose Peptone No. 3 or 0.3 per cent Evans Peptone may be substituted for Orthana Peptone.

Inoculation: The tubes are inoculated with 1 loopful of a $24 \mathrm{hr}$. broth culture grown at $370 \mathrm{C}$.

Incubation: Tests are incubated at $37{ }^{\circ} \mathrm{C}$ and observed daily for 2 days. Positive results are indicated by growth in the presence of KCN.

Test No. 16

Motility test. Medium.

$\begin{array}{lr}\text { Beef extract } & 3 \mathrm{gms} . \\ \text { Peptone } & 10 \mathrm{gms} \text {. } \\ \text { Sodium chloride } & 5 \mathrm{gms} . \\ \text { Agar } & 2.5 \mathrm{gms} . \\ \text { Distilled water } & 1000 \mathrm{ml} .\end{array}$

Any good peptone may be used. Adjust reaction to $\mathrm{pH} 7.4$ and tube, about $8 \mathrm{ml}$. per tube, and sterilize at $121^{\circ} \mathrm{C}, 15 \mathrm{~min}-$ utes.

Inoculate by stabbing into the top of the column of medium to a depth of about $5 \mathrm{~mm}$.

Incubation: $370 \mathrm{C}$ for 2 -days. If negative, follow with further incubation at 21 to $25^{\circ} \mathrm{C}$ for 5 days. 
B A C T ER I OLOGICAL NOMENCLA T URE A N D T A X O N O M Y

Test No. 17

Motility test. Alternate method.

Peptone
Meat extract
NaCl
Kobe agar
Distilled water
$10 \mathrm{gms}$.

5 gms.

3 gms.

2.25 gms.

$1000 \mathrm{ml}$.

Any good peptone and meat extract may be employed. Adjust reaction to $\mathrm{pH} 7.4$. Sterilization, inoculation, and incubation are the same as that given for lest No. 16.

$$
\text { Test No. } 18
$$

Phenylalanine agar. Test for deamination of phenylalanine to phenylpyruvic acid.

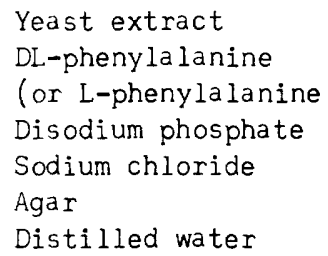

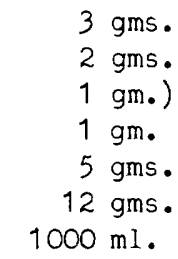

Tube and sterilize at $121^{\circ} \mathrm{C}$ for 10 minutes and allow to solidify in a slanted position (long slant).

Test reagent: 10 per cent $(w / v)$ solution of ferric chloride. Inoculation: Inoculate the slant of the PA agar with a fairly heavy inoculum from an agar slant culture.

Incubation: $4 \mathrm{hrs}$. or, if desired 18 to $24 \mathrm{hrs}$. at $370 \mathrm{C}$.

Following incubation, 4 or 5 drops of ferric chloride reagent are allowed to run down over the growth on the slant. If phenylpyruvic acid has been formed a green color develops in the syneresis fluid and in the slant. 
Page 66

I N T ER N A T I ONAL BULLETIN

Test No. 19

Phenylalanine. Alternate method.

Inoculate the whole surface of an agar slant. Incubate overnight; if growth is good, suspend in $0.5 \mathrm{ml}$. saline. Occasional strains (though rarely Proteus strains), give insufficient growth, in which case the growth from several slants should be used. The suspension should contain about 50,000 million organisms or more, but need not be standardized. Transfer the suspension to a test tube and add $0.5 \mathrm{ml}$. of 0.2 per cent DL-phenylalanine in saline (or 0.1 per cent L-phenylalanine), preserved with 0.01 per cent merthiolate. Add 1 drop of 0.01 per cent phenol red and make alkaline with $\mathrm{M} / 10 \mathrm{Na}_{2} \mathrm{CO}_{3}$. Shake vigorously and place tubes nearly flat on a table. Leave for 4 hours and add 10 per cent $\mathrm{H}_{2} \mathrm{SO}_{4}$ dropwise until the color changes through yellow to pink. Add sufficient $\left(\mathrm{NH}_{4}\right)_{2} \mathrm{SO}_{4}$ to saturate the solution and then 4 or 5 drops of half-saturated $\mathrm{FeNH}_{4}\left(\mathrm{SO}_{4}\right)_{2}$. Shake well and read results when the green color is at a maximum or, if negative, after about 1 minute.

Positive reactions are graded as + (faint greenish color), ++ (distinct, but weak or only moderately strong green color), and +H (dark green to bluish-green color).

Henriksen, S. D. Jour. Bact. 60:225-231. 1950.

Test No. 20

Sodium malonate broth. Test for utilization of malonate.

Yeast extract
Ammonium sulfate
Dipotassium phosphate
Monopotassium phosphate
Sodium chloride
Sodium malonate
Bromthymol blue
Distilled water

Sterilize at $1210 \mathrm{C}$ for 15 minutes.

\author{
$1 \mathrm{gm}$. \\ 2 gms. \\ $0.6 \mathrm{gm}$. \\ $0.4 \mathrm{gm}$. \\ 2 gms. \\ 3 gms. \\ $0.025 \mathrm{gm}$. \\ $1000 \mathrm{ml}$.
}


B A C I ER I OLOGICAI NOMENCLATURE A N D T T A X O N O M Y

Inoculation: Inoculate from a young agar slant culture.

Incubation: $370 \mathrm{C}$ for 48 hours.

Positive results are indicated by a change in the color of the indicator from green to Prussian blue.

\section{Additional Biochemical Tests}

There are a number of additional tests and methods that are of considerable value in the differentiation of strains that belong to certain groups of Enterobacteriaceae. These are listed below:

The Ninhydrin Test of Carlquist (1956). This test is of particular value in the differentiation of members of the Salmonella and Arizona groups on the one hand, from Citrobacter (including Bethesda-Ballerup) strains on the other. The majority of cultures that belong to the Salmonella and Arizona groups give positive tests while, with few exceptions, Citrobacter strains are negative (Edwards, Fife, and Ewing, 1956). The test is also of value in the differentiation of shigellae and Escherichia cultures of the Alkalescens-Dispar biotypes. The shigellae are negative when tested by the ninhydrin method of Carlquist, whereas the majority of Alkalescens-Dispar cultures are positive.

The amino acid decarboxylase tests of Moeller (1954a, 1954b, 1955). These include tests for decarboxylation of lysine, arginine, ornithine, and glutamic acid, all of which are of value in taxonomic studies in the Enterobacteriaceae. It should be noted that within certain groups $\mathrm{e} . \mathrm{g}$. the Cioaca (Aerobacter) group the results obtained with the lysine decarboxylase test described by Moeller (1954b) and the ninhydrin method of Carlquist (1956) may not be comparable. Hence, it is very important to designate the method employed, particularly in published reports.

Christensen's Citrate Agar (1949). Test for citrate utilization in the presence of organic nitrogen. This method is of particular value in the differentiation of shigellae and Escherichia cultures of the Alkalescens-Dispar biotypes (Edwards, Fife, and Ewing, 1956). 
Page 68

I N IER A T IONALBULLETIN

Organic Acid Iests. The organic acid tests, L-tartrate, D-tartrate, M-tartrate, sodium citrate, and mucate, are also of considerable value, particularly in certain areas within the Enterobacteriaceae (see Kauffmann and Petersen, 1956).

Reduction of nitrates. Although the nitrate reduction test is of little or no value for group differentiation within the Enterobacteriaceae, it is included because a negative test is often of value in the exclusion of otherwise doubtful strains. The results of negative nitrate tests should always be confirmed. This may be done by adding a minute amount of zinc dust to the tube. The development of a red color indicates the presence of unreduced nitrate.

$\begin{array}{lr}\begin{array}{l}\text { Potassium nitrate } \\ \quad(\text { nitrite free) }\end{array} & 0.2 \mathrm{gm} . \\ \text { Peptone } & 5.0 \mathrm{gms} . \\ \text { Distilled water } & 1000 \mathrm{ml} .\end{array}$

Tube in $5 \mathrm{ml}$. amounts and sterilize at $121^{\circ} \mathrm{C}$, for 15 minutes on each of three successive days. After inoculation from an agar slant culture the medium is incubated at $370 \mathrm{C}$, for 4 days.

\section{Test reagents}

\section{A. Dissolve 8.0 grams of sulfanilic acid in $1000 \mathrm{ml}$. of 5 normal acetic acid. \\ B. Dissolve 5.0 grams of alphanaphthylamine in $1000 \mathrm{ml}$. of 5 normal acetic acid.}

Immediately before use equal parts of solutions $A$ and $B$ are mixed and $0.1 \mathrm{ml}$. of the mixture is added to each culture. Positive tests for reduction of nitrate to nitrite are indicated by the development of a red color within a few minutes.

Nitrate reduction. Alternate method.

\author{
Tryptone \\ Neopeptone \\ Agar \\ Distilled water
}

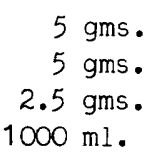

5 gms.

$2.5 \mathrm{gms}$.

$1000 \mathrm{ml}$. 
Page 69

B A C TER I OLOGICAI NOMENCLATURE A N D I A X O NOMY

Boil and adjust $\mathrm{pH}$ to $7.3-7.4$ then add

$$
\begin{array}{ll}
\mathrm{KNO}_{3} \text { (nitrite free) } & 1.0 \mathrm{gm} . \\
\text { Glucose } & 0.1 \mathrm{gm} .
\end{array}
$$

Sterilization: $121^{\circ} \mathrm{C}, 15$ minutes.

Inoculation: The medium may be inoculated by stabbing into the column of semisolid agar medium.

Incubation: $370 \mathrm{C}, 24 \mathrm{hrs}$. The occasional culture that gives apparently equivocal results should be retested after $1,2,3$, and 4 days' incubation.

\section{Test reagents}

The sulfanilic acid and alphanaphthylamine reagents given above ( $A$ and $B$ ) are used in the same manner.

\section{References for Additional Tests}

Carlquist, P. R. 1956. Jour. Bact. 71:339-341.

Edwards, P. R., Fife, M. A., and Ewing, W. H. 1956. Amer. Jour. Med. Technol. 22:28-35.

Kauffmann, F. and Petersen, A. 1956. Acta Path. Microbiol. Scand. 38:481-491.

Moeller, V. 1954a. Acta Path. Microbiol. Scand. 34:102-114. 1954b. ibid. $35: 259-277$. 1955. ibid. $36: 158-172$. 
GROUP DIFFERENTIATION OF ENTEROBACTERIACEAE BY BIOCHEMICAL TESTS

(REACTIONS OF TYPICAL CULTURES OBTAINED WITH RECOMMENDED METHODS)

\begin{tabular}{|c|c|c|c|c|c|c|c|c|c|c|c|c|c|c|c|}
\hline \multirow{2}{*}{ GROUP } & \multirow{2}{*}{$\begin{array}{l}\text { Salmon- } \\
\text { ella }\end{array}$} & \multirow{2}{*}{ Arizona } & \multirow{2}{*}{$\begin{array}{r}\text { Citro- } \\
\text { bacter } \\
\end{array}$} & \multirow{2}{*}{ Shige lla } & \multirow{2}{*}{$\begin{array}{c}\text { Escher- } \\
\text { ichia }\end{array}$} & \multirow{2}{*}{$\begin{array}{l}\text { Kleb- } \\
\text { siella }\end{array}$} & \multirow{2}{*}{$\begin{array}{l}\text { Aero- } \\
\text { bacter } \\
\text { or } \\
\text { Cloaca }\end{array}$} & \multicolumn{2}{|c|}{ Ha fnia } & \multirow{2}{*}{ Serratia } & \multicolumn{4}{|c|}{ Proteus } & \multirow{2}{*}{$\begin{array}{l}\text { Provi- } \\
\text { dence }\end{array}$} \\
\hline & & & & & & & & $370 \mathrm{C}$ & $22^{\circ} \mathrm{C}$ & & vulgaris & mirabilis & morganii & $\widehat{\text { rettgeri }}$ & \\
\hline $\begin{array}{r}\text { Gas from Glucose } \\
\text { Lactose } \\
\text { Sucrose } \\
\text { Mannitol } \\
\end{array}$ & $\begin{array}{l}+ \\
- \\
- \\
+\end{array}$ & $\begin{array}{r}+ \\
+ \\
+ \\
+ \\
\end{array}$ & $\begin{array}{r}+ \\
+ \text { or } x \\
d \\
+ \\
\end{array}$ & $\begin{array}{l}-* \\
-* \\
-* \\
d\end{array}$ & $\begin{array}{l}+ \\
+\quad \text { or } x \\
d \\
+ \\
\end{array}$ & $\begin{array}{l}+ \\
+ \\
+ \\
+ \\
\end{array}$ & $\begin{array}{r}+ \\
+ \text { or } x \\
+ \\
+ \\
\end{array}$ & $\begin{array}{r}d \\
-\quad \text { or } x \\
x \\
+ \\
\end{array}$ & $\begin{array}{r}+ \\
- \text { or } x \\
x \\
+ \\
\end{array}$ & $\begin{array}{l}d \\
- \text { or } x \\
+ \\
+ \\
\end{array}$ & $\begin{array}{l}+ \\
- \\
+ \\
-\end{array}$ & $\begin{array}{l}+ \\
- \\
x \\
-\end{array}$ & $\begin{array}{l}+ \\
- \\
d \\
\end{array}$ & $\begin{array}{l}d \\
- \\
d \\
+\end{array}$ & $\begin{array}{l}d \\
- \\
d \\
d\end{array}$ \\
\hline $\begin{array}{l}\text { Dulcitol } \\
\text { Salicin } \\
\text { Adonitol } \\
\text { Inositol } \\
\end{array}$ & $\begin{array}{l}d \\
- \\
d\end{array}$ & $\begin{array}{l}- \\
- \\
z\end{array}$ & $\begin{aligned} & d \\
& d- \\
&- \text { or } x \\
&\end{aligned}$ & $\begin{array}{l}\text { d } \\
z\end{array}$ & $\begin{array}{l}d \\
d \\
- \\
-\end{array}$ & $\begin{array}{l}d \\
+ \\
+ \\
+ \\
\end{array}$ & $\begin{array}{l}d \\
+ \\
d \\
d\end{array}$ & $\begin{array}{l}- \\
\text { d } \\
\text { z }\end{array}$ & $\begin{array}{l}\text { d } \\
- \\
\end{array}$ & $\begin{array}{l}- \\
+ \\
d \\
d\end{array}$ & $\begin{array}{l}- \\
+ \\
- \\
-\end{array}$ & $\begin{array}{l}\bar{z} \\
\text { d } \\
-\end{array}$ & $\begin{array}{l}- \\
- \\
-\end{array}$ & $\begin{array}{l}- \\
d \\
+ \\
+ \\
\end{array}$ & $\begin{array}{l}- \\
- \\
d \\
d\end{array}$ \\
\hline $\begin{array}{l}\text { Indol } \\
\text { Methyl Red } \\
\text { Voges-Proskauer } \\
\text { Ammonium citrate }\end{array}$ & $\begin{array}{l}- \\
+ \\
- \\
+\end{array}$ & $\begin{array}{l}- \\
+ \\
+ \\
+\end{array}$ & $\begin{array}{l}- \\
+ \\
+ \\
+\end{array}$ & $\begin{array}{l}d \\
+ \\
- \\
-\end{array}$ & $\begin{array}{l}+ \\
+ \\
- \\
-\end{array}$ & $\begin{array}{l}- \\
- \\
+ \\
+\end{array}$ & $\begin{array}{l}- \\
+ \\
+ \\
+\end{array}$ & $\begin{array}{l}- \\
+ \\
d \\
d\end{array}$ & $\begin{array}{l}- \\
- \\
+ \\
+\end{array}$ & $\begin{array}{l}- \\
+ \\
+ \\
+\end{array}$ & $\begin{array}{l}+ \\
+ \\
- \\
d\end{array}$ & $\begin{array}{l}- \\
+ \\
d \\
d\end{array}$ & $\begin{array}{l}+ \\
+ \\
- \\
\end{array}$ & $\begin{array}{l}+ \\
+ \\
+ \\
+\end{array}$ & $\begin{array}{l}+ \\
+ \\
- \\
+\end{array}$ \\
\hline $\begin{array}{l}\text { Hydrogen sulfide } \\
\text { Urease } \\
\text { Gelatin } \\
\text { KCN }\end{array}$ & $\begin{array}{l}+ \\
- \\
-\end{array}$ & $\begin{array}{l}+ \\
- \\
(+) \\
-\end{array}$ & $\begin{array}{l}+ \\
- \\
+ \\
+\end{array}$ & $\begin{array}{l}- \\
- \\
-\end{array}$ & $\begin{array}{l}- \\
- \\
-\end{array}$ & $\begin{array}{l}- \\
\dot{(+)} \\
+ \\
\end{array}$ & $\begin{array}{l}- \\
d \\
d \\
+\end{array}$ & $\begin{array}{l}- \\
- \\
+\end{array}$ & $\begin{array}{l}(+) \\
- \\
+ \\
+\end{array}$ & $\begin{array}{l}- \\
- \\
+ \\
+ \\
\end{array}$ & $\begin{array}{l}+ \\
+ \\
+ \\
+ \\
\end{array}$ & $\begin{array}{l}+ \\
+ \\
+ \\
+ \\
\end{array}$ & $\begin{array}{l}- \\
+ \\
+ \\
\end{array}$ & $\begin{array}{l}- \\
+ \\
+ \\
\end{array}$ & $\begin{array}{l}- \\
\pm\end{array}$ \\
\hline $\begin{array}{l}\text { Motility } \\
\text { Phenylalanine } \\
\quad \text { deaminase } \\
\text { Malonate }\end{array}$ & $\begin{array}{l}+ \\
- \\
\end{array}$ & $\begin{array}{l}+ \\
+ \\
+\end{array}$ & $\begin{array}{l}+ \\
- \\
-\end{array}$ & $\begin{array}{l}- \\
-\end{array}$ & $\begin{array}{l}+ \\
- \\
-\end{array}$ & $\begin{array}{l}- \\
+ \\
+\end{array}$ & $\begin{array}{l}+ \\
- \\
d\end{array}$ & $\begin{array}{l}d \\
\text { d }\end{array}$ & $\begin{array}{l}+ \\
- \\
d\end{array}$ & + & $\begin{array}{l}+ \\
+ \\
+\end{array}$ & $\begin{array}{l}+ \\
+ \\
-\end{array}$ & $\begin{array}{l}+ \\
+ \\
+\end{array}$ & $\begin{array}{l}+ \\
+ \\
+\end{array}$ & $\begin{array}{l}+ \\
+ \\
+\end{array}$ \\
\hline & & $\begin{array}{ll}+ & P \\
x & L \\
- & N \\
d & D\end{array}$ & $\begin{array}{l}\text { ositive } 1 \\
\text { ate and } 1 \\
\text { legative. } \\
\text { ifferent }\end{array}$ & $\begin{array}{l}\text { or } 2 \text { days. } \\
\text { rregularly } \\
\text { biochemical }\end{array}$ & $\begin{array}{l}\text { positive. } \\
\text { types. }\end{array}$ & & & $\begin{array}{ll}+1) & c \\
& h \\
* & 5 \\
& c \\
* & c\end{array}$ & $\begin{array}{l}\text { Gelatin } 1 \\
\text { aydrogen } \\
\text { Shigella } \\
\text { Certain b } \\
\text { Gitrobact }\end{array}$ & $\begin{array}{l}\text { fied s } \\
\text { fide pro } \\
\text { hel fern } \\
\text { ypes of } \\
\text { group, }\end{array}$ & $\begin{array}{l}\text { ly, urea } \\
\text { ced slowl } \\
\text { ts lactos } \\
\text { flexneri } \\
\text { luding } B e\end{array}$ & $\begin{array}{l}\text { hydrolysed } \\
\text { y and in sm } \\
\text { se and sucro } \\
6 \text { produce } \\
\text { thesda-Ball. }\end{array}$ & $\begin{array}{l}\text { slowly, or } \\
\text { all amount } \\
\text { se slowly. } \\
\text { gas. } \\
\text { erup. }\end{array}$ & & \\
\hline
\end{tabular}

